УДК: 37.091.12:005.963]:004

DOI: 10.26697/ijes.2019.2.19

\section{Оцінювання результатів підвищення кваліфікації вчителів засобами Moodle}

Польгун К. В. ${ }^{1}$

${ }^{1}$ Криворізький університет, Україна

державний педагогічний

Резюме

Вступ:

Курси підвищення кваліфікації (КПК) вчителів - це важливий складник системи неперервної освіти, який надає вчителям змогу систематично поновлювати знання та підвищувати рівень професійної компетентності. Поміж підстав для видачі свідоцтва про проходження КПК $\epsilon$ отримання позитивної рецензії на кваліфікаційну роботу. Як показує досвід, така форма роботи все більше набуває ознак формалізму й потребує осучаснення. Натомість використання засобів Moodle здатне забезпечити об'єктивність оцінювання результатів підвищення кваліфікації вчителів.

Мета публікації - аналіз досвіду впровадження електронного тестування на КПК вчителів у Криворізькому державному педагогічному університеті.

\section{Результати:}

У Системі управління електронними навчальними курсами (СУЕНК) Криворізького державного педагогічного університету (https://moodle.kdpu.edu.ua) в межах категорії “Курси підвищення кваліфікації вчителів" створено електронні навчальні курси за відповідними спеціальностями. Вони містять три типи тестів.

1. Тестові завдання для тренування. Кожен тест передбачає завдання 3 однієї тематики. Кількість спроб і тривалість тестування необмежені. Порядок запитань сталий. Місце й час тестування користувач може обрати самостійно. Доступна робота через мобільний додаток. Завдання відкриті протягом усього терміну проведення КПК.

2. Пробне контрольне тестування. Доступна одна спроба. Обмеження в часі - 40 хв. Користувач може обрати довільні місце й час тестування. Тест доступний протягом доби, напередодні дня контрольного тестування. Мета пробного контрольного тестування - ознайомити вчителів 3 умовами контрольного тесту. Так, тест складається 330 тестових завдань, 20 з яких стосуються предмета та методики його навчання, 6 педагогіки й психології, 2 - нормативно-правової бази. Вибірка здійснюється випадковим чином із банку питань. Відповідно, кожен користувач має власний варіант завдань.

3. Підсумкове контрольне тестування. Відмінність між пробним і контрольним тестуванням полягає в тому, що останне проводиться в аудиторії зі спостерігачами. Вчителі не можуть користуватися додатковими матеріалами й пристроями.
Для наповнення тестів викладачами відповідних кафедр попередньо було створено банк тестових завдань: 200 для перевірки професійного складника (100 з предмету, 100 - 3 методики його навчання), 100 - для перевірки психолого-педагогічного складника (35 завдань стосувалися педагогіки, 35 психології, 30 - нормативно-правової бази в галузі освіти). Усі питання рівнозначні, мають однаковий тип та структуру.

Тестування в СУЕНК проходили 54 особи. Усі результати виявилися позитивними (83 бали і більше - зі 100 можливих).

Наявність тренувальних тестів значною мірою вплинула на формування готовності вчителів до проходження підсумкового тестування. Необмежена кількість спроб сприяла тому, що вчителі самі могли розрахувати свій час і вирішити, коли $\mathrm{i}$ в якому обсязі вони мають пройти тренувальні тести. Можливість роботи 3 відповідним мобільним додатком значно розширила доступність тестів, забезпечила гнучкість системи навчання та реалізацію принципу “навчання в будь-якому місці, в будьякий час".

Опитування вчителів засвідчило, що вони отримали позитивні враження від електронного тестування.

Процедура оцінювання результатів проходження КПК вчителів значно спростилася. Певних зусиль вимагає лише розроблення тестових питань, однак ця робота виконується одноразово лише на підготовчому етапі.

Важливе значення має технічне забезпечення процесу підсумкового контрольного тестування, зокрема стан персональних комп'ютерів і доступ до мережі Інтернет.

\section{Висновки:}

Загалом досвід упровадження електронного тестування на КПК вчителів можна вважати успішним. Відповідно, перспективним $є$ поширення практики використання засобів Moodle на КПК вчителів усіх спеціальностей.

\section{Інформація про автора:}

Польгун Катерина В'ячеславівна - кандидат педагогічних наук, асистент кафедри математики та

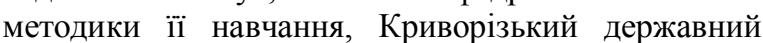
педагогічний університет, Кривий Ріг, Україна.

Наукові інтереси: освіта і навчання, математична освіта, ІКТ в освіті, е-навчання, методика навчання математики; https://orcid.org/0000-0001-5914-0153.

\section{Автор-Кореспондент:}

Польгун Катерина В’ячеславівна

Email Автора-Кореспондента: polgun@kdpu.edu.ua 